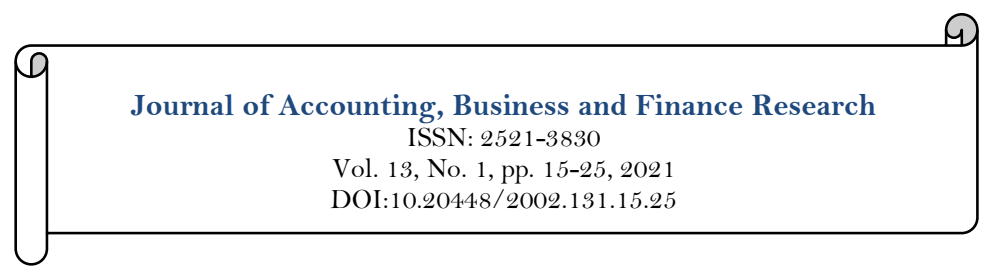

\title{
Investigating the Demographic Characteristics of Institutional Investors Affecting Representativeness, Conservatism and Overconfidence Biases in Individual Investments
}

\section{Idil Ozlem Koc}

Professor of Finance, School of Banking and Insurance, Marmara University, Istanbul, Turkey. Email:iokoc@marmara.edu.tr

\begin{tabular}{|c|c|}
\hline Abstract & \\
\hline $\begin{array}{l}\text { This study aims to identify the factors affecting representativeness, } \\
\text { conservatism, and overconfidence biases in a sample of Turkish } \\
\text { institutional investors. This study is different to other studies in that it } \\
\text { focuses on the individual investments of institutional investors in capital } \\
\text { markets. The respondents, who were selected via the convenience } \\
\text { sampling method, were asked survey questions. In the study, models are } \\
\text { formed with the stepwise method using linear regression analysis, and } \\
\text { survey questions that represent the examined biases are selected as the } \\
\text { dependent variables. The age, gender, marital status, education, having } \\
\text { children, and the experience of institutional investors are included in the } \\
\text { analysis as the independent variables. This way, we can reveal which of the } \\
\text { independent variables are statistically significant and which of the } \\
\text { subcategories of the independent variables are most influential on the } \\
\text { biases. As a result of the analysis, in addition to determining the variables } \\
\text { that affect a single bias, education level affects all examined biases, } \\
\text { especially low education, which is higher. In the regression analysis, } \\
\text { experience is identified as a significant variable affecting } \\
\text { representativeness and conservatism biases. It is observed that the } \\
\text { institutional investors who are inexperienced or less experienced interact } \\
\text { with these two biases more in their decisions related to their individual } \\
\text { investments. Gender is found to be a significant variable on both } \\
\text { conservatism and representativeness biases, and female institutional } \\
\text { investors are more effective than men on the representativeness and } \\
\text { conservatism bias. Furthermore, it is determined that the marital status } \\
\text { variable and the divorced institutional investors are significantly } \\
\text { influential on conservatism and overconfidence biases. }\end{array}$ & $\begin{array}{l}\text { Keywords: } \\
\text { Overconfidence bias } \\
\text { Conservatism bias } \\
\text { Representativeness bias } \\
\text { Demographic factors } \\
\text { Institutional investor } \\
\text { Individual investment. } \\
\text { JEL Classification: } \\
\text { G11, G23, G41. } \\
\text { Licensed: } \\
\text { This work is licensed under a } \\
\text { Creative Commons Attribution } 4.0 \\
\text { License. } \\
\text { Publisher: } \\
\text { Scientific Publishing Institute } \\
\text { Received: } 14 \text { July } 2021 \\
\text { Revised: } 23 \text { August } 2021 \\
\text { Accepted: } 7 \text { September } 2021 \\
\text { Published: } 20 \text { September } 2021\end{array}$ \\
\hline
\end{tabular}

Funding: This study received no specific financial support.

Competing Interests: The author declares that there are no conflicts of interest regarding the publication of this paper.

\section{Introduction}

Pronin, Lin, and Ross (2015) stated that there are biases in the decisions of investors. Furthermore, psychologists argued that although biases are known, it is difficult to reduce their effects (Pronin et al., 2015). Chen, Kim, Nofsinger, and Rui (2007) found that 43\% of investors are affected by more than one bias. Bhandari and Deaves (2006) also inspired studies by asking "Do these (demographic characteristics such as age, investment experience, education, income and wealth) influence the existence and degree of overconfidence?" 
Lin (2011) investigated the formation of biases in his study, stating that the possible effects of biases attract the attention of individual investors.

Many studies in the literature examined the interaction of demographic characteristics and behavioral biases in making decisions regarding investments by individual or institutional investors. This study focuses on the individual investments of institutional investors. Consequently, it was investigated which demographic characteristics of institutional investors' decisions regarding individual investments affect representativeness, conservatism, and overconfidence biases using Turkish institutional investors as the sample.

The overconfidence bias has been the subject of many studies in the research on investors' biases (Asad, Khan, \& Faiz, 2018; Baker, Kumar, Goyal, \& Gaur, 2019; Barber \& Odean, 2001; Bhandari \& Deaves, 2006; Chen et al., 2007; Deaves, Lüders, \& Luo, 2009; Prims \& Moore, 2017; Prosad, Kapoor, \& Sengupta, 2015). Therefore, this study examines the conservatism and representativeness biases as well as the overconfidence bias. The demographic factors of age, gender, marital status, education, number of children, and experience were examined. As mentioned above, another difference of this study from other studies is that it focuses on the individual investments of institutional investors. In other words, this work is based on the individual investments of institutional investors and their interaction with biases instead of the investments made professionally by institutional investors. ${ }^{1}$

In summary, in this study, the interaction between the demographic characteristics and the biases was examined to determine which demographic characteristics affect biases. The paper comprises four sections. The next section focuses on the literature review, Section 3 outlines the sample and the research methodology, and Section 4 presents and discusses the results of the study.

\section{Literature Review}

\subsection{Investor Demographic Characteristics and Behavioral Biases}

Gender: Many studies have found that in financial investments, women are relatively more risk-averse than men (Graham, Stendardi, Myers, \& Graham, 2002). Moreover, Jianakoplos and Bernasek (1998) asserted that the gender difference in financial risk-taking is also affected by age, race, and number of children. Studies have also determined that women tend to focus on low-risk assets with a fixed income rather than risky assets (Graham et al., 2002). Furthermore, Lease, Lewellen, and Schlarbaum (1976) concluded that older females prefer to diversify and make dividend-oriented investments. Regarding gender in terms of bias, it was concluded that women refrain from investing in risky assets and avoid risk, so women are less likely to be affected by the overconfidence bias than men. Beatrice, Murhadi, and Herlambang (2021) also stated that women are less confident than men.

In the literature, the majority of studies are on gender and overconfidence bias. Nofsinger, Patterson, and Shank (2018) discovered that the effects of testosterone and cortisol on the nucleus accumbens of the brain can affect investors' risk preferences and confidence levels. Accordingly, Barber and Odean (2001); Barber and Odean (2001) and Prosad et al. (2015) reported that men increase their trade volume by being more affected by the overconfidence bias than women, but the resulting returns are lower than those of women. Daniel, Hirshleifer, and Subrahmanyam (2005) stated that investors with the overconfidence bias underestimate their securities risks because they overestimate their abilities. Barber and Odean (2001) and Bhandari and Deaves (2006) also found that male investors act with more overconfidence bias than female investors.

Dwyer, Gilkeson, and List (2002) observed that women make less risky mutual fund investments. Dwyer et al. (2002) found that when they included "financial investment information" as a control variable in their study, the gender distinction in investment asset preference largely disappeared. Women are more likely than men to invest in certificate of deposits and mutual funds weighted by money market instruments (Lascu, Babb, \& Phillips, 1997). Barber and Odean (2001) showed that women's stock portfolios are lower than men's stock portfolios. Martenson (2008) noted that female investors avoid taking risks more than men in their investment decisions. He also revealed that not all male investors behave in the same way. Accordingly, he concluded that men, who are optimistic in their investment perspective, act with more overconfidence, take risks, and invest in futures and options markets, and on the other hand, pessimistic male investors prefer to take risks but invest in stock markets with more limited risk. Graham et al. (2002) revealed that, compared to male investors, female investors avoid taking risks and have less confidence in their investments, they also trade less and the data processing is different from men. Barber and Odean (2001) confirmed that women have less overconfidence and take less action. Deaves et al. (2009) could not find a significant difference between men and women in terms of being affected by the overconfidence bias. Prosad et al. (2015) emphasized that male investors have more overconfidence than female investors because of their greater knowledge of the Indian stock market. According to Barber and Odean (2001), men's operations on common stock were 1.5 times that of women, which is consistent with the effect of overconfidence. 1. In the other study, which is in the peer review process, whether or not an institutional investor deviates from their rational investor identity in their
individual investments is investigated, and it is concluded that the institutional investor is affected by behavioral biases by showing normal investor behavior in their individual investment decisions. 
Age: Results regarding the relationship between age and biases are varied in the literature (Prims and Moore, 2017). Prosad et al. (2015) showed that older people are prone to the biases. Chen et al. (2007) reported that older investors, who have more life experience than young people, make worse choices than other investors and are unable to diversify when necessary. Lease et al. (1976), on the other hand, showed that older investors attach less importance to short-term capital gains; they are more interested in dividends and they prefer diversified portfolios and avoid investing in high-risk assets. Gervais and Odean (2001) also demonstrated that younger investors invest more actively and expect to earn more income than older investors, but they can earn a relatively low income from a portfolio with a "buy and hold" strategy. Baker et al. (2019) also reached a different result. Accordingly, investors over the age of 60 are less prone to representativeness bias than young people. Prims and Moore (2017) stated that the widespread belief regarding investors' age and overconfidence bias is that younger people are more aggressive, more prone to risk taking, and are under the influence of overconfidence bias. But some studies also indicated that, although young people are prone to risky investments, they do not need to act with overconfidence. In addition, Prims and Moore (2017) stated that, as an investor ages, they behave more cautiously, but overconfidence bias leads them to take more risks. Bashir, Azam, Butt, Javed, and Tanvir (2013) identified a positive relationship between age and overconfidence bias in their study. Baker et al. (2019) also found that retired investors have more overconfidence.

Marital Status: Barber and Odean (2001) stated that, in general, married men trade more in the capital market than married women, and this also applies to single men and women. Moreover, when married women and married men were compared, a difference in investment amount was found between them, and this difference is greater than between single men and single women. Barber and Odean (2001) reported that married women are less likely to take risks than married men and thus invest less in common stock, which is a risky investment instrument. This view is similar to what is generally believed regarding female investors. It was also deduced that if couples affect each other's investment decisions, gender differences in terms of overconfidence would disappear (Barber \& Odean, 2001). The study by Ateş, Coşkun, Şahin, and Demircan (2016) found that unmarried investors are more affected by the overconfidence bias than those who are married.

Education: Chen et al. (2007) acknowledged that being affected by bias due to different experiences in education and cultural life will lead to a differentiation in people's decisions. Nikiforow (2009) expressed that education on behavioral finance reduced the tendency of finance sector employees to be affected by the biases. Dwyer et al. (2002) also reported that investors with higher income and more education tend to take more risks. Dreman and Berry (1995) declared that interacting historical information regarding stocks plays a role in future inferences for stocks. Moreover, when the representativeness bias is associated with education, Baker et al. (2019) found that those who graduated or have post-graduate education are less affected by the representativeness bias. Ateş et al. (2016) also stated that the representativeness bias generally affects the decisions of groups with a lower education level. Likewise, Goo, Chen, Chang, and Yeh (2010) asserted that those with a high level of education will be confident in the decisions they make and will not be affected by other people's knowledge and investment decisions (Beatrice et al., 2021). Bhandari and Deaves (2006) stated that investors who did not receive a special education specific to investment make decisions under the influence of the overconfidence bias, considering that they make their investments well with their general education. In particular, when they surveyed a group that would soon retire, they found that this group was affected by the overconfidence bias. Beatrice et al. (2021), on the other hand, found that education is not related to overconfidence, and even if the investor does not have an education on capital markets, they can educate themselves with the developing technology. In other words, investors will improve themselves with additional education, increase their knowledge of investment, and will not need to make decisions with overconfidence. In fact, Bhandari and Deaves (2006) revealed that investors with a high level of education think they are more knowledgeable because they are overconfident in the results of their decisions (Beatrice et al., 2021).

Experience: Deaves et al. (2009) stated that experience allows a person to understand their knowledge and limits regarding their expertise. Gervais and Odean (2001); Barber and Odean (2001) and Chen et al. (2007) argued that investors who take part in frequent or large trade activities will learn more and gain more experience. Moreover, Deaves et al. (2009) asserted that the experience gained in professional life will not only provide an individual with awareness and wisdom but also reduce their achievement motivation. In this sense, in time, experienced investors reduce their trade volume, are not affected by behavioral biases, and display rational behavior related to investment. By reducing their error rate, a reduced trade volume will allow experienced investors to avoid risky investments and be more involved in diversification (Deaves et al., 2009). Gervais and Odean (2001) and Menkhoff, Schmeling, and Schmidt (2013) showed that investors are more overconfident at the beginning of their careers, but their level of overconfidence decreases as their experience increases. Gervais and Odean (2001) claimed that experience will increase overconfidence to at least a small extent. Barber and Odean (2001) associated excessive trading behavior among investors with their acts under the influence of the overconfidence bias. Gervais and Odean (2001) acknowledged that successful investors, albeit not all of them, are overconfident. Prosad et al. (2015) found that investors with more than seven years 
of experience with high trade volumes have an interaction with all biases. Deaves et al. (2009) also stated that experience will lead individuals to becoming overconfident while degrading their existing knowledge. Accordingly, the authors determined that investment experience and overconfidence bias are associated. Likewise, Mishra and Metilda (2015) reported that, along with experience, the overconfidence of investors also increases. Sharing the same view as Mishra, Baker et al. (2019) observed that investors with several years of experience had higher levels of overconfidence in comparison to those with two years' experience at most. Deaves et al. (2009) showed that investors with high levels of experience related to financial markets are more overconfident. However, they also determined that the degree of overconfidence will decrease as experience increases further. Different results have been obtained regarding the relationship between experience and overconfidence bias (Deaves et al., 2009). Baker et al. (2019) and Bhandari and Deaves (2006) reported that retired investors were more overconfident than actively working investors. Here, the correlation between age and experience was very high. Additionally, Baker et al. (2019) revealed that retired investors made decisions in their investments largely under the influence of the representativeness bias, thus indicating an association between representativeness bias and experience.

\section{Sample Design and Analysis}

\subsection{The Sample}

Studies in the literature have investigated the relationships between the individual biases and demographic characteristics of both individual investors and institutional investors in many cultures (Asad et al., 2018; Baker et al., 2019; Barber \& Odean, 2001; Bhandari \& Deaves, 2006; Chen et al., 2007; Deaves et al., 2009; Mishra \& Metilda, 2015; Prims \& Moore, 2017; Prosad et al., 2015). Past studies show that cultural differences affect individuals' behavior (Ji, Zhang, \& Guo, 2008). Considering this issue, this study covers institutional investors in the Turkish finance sector. The respondents were asked questions on the individual investments they held, with the aim of establishing a relationship between biases that may be effective on the decisions of institutional investors regarding their individual investments and their individual demographic characteristics. In a previous study of mine, which was in the peer review process at the time of writing this article, I determined that while making individual investments, an institutional investor may deviate from their identity as a rational investor, be influenced by some biases, and make decisions about their individual investments like a normal (irrational) investor. Therefore, in this study, which may be considered an addition to the previous one, by using the conclusion that institutional investors are affected by biases while making their individual investments, I aim to determine which demographic factors affect the biases of institutional investors. Using the method of convenience sampling, 346 institutional investors working in Istanbul in Turkey were contacted. The survey was conducted in person or by sending the form directly to the participants.

Table 1 summarizes the data collected from the sample, of which about $40 \%$ were female and $60 \%$ were male. In terms of age range, the 21-30 age group constituted the majority in sample. The majority of them were married couples, followed by singles. In the sample, the rate of those who had no children was quite high. The percentage of college and university educated people was higher than the percentage of masters and Ph.D. education. The education that the participants received was organized into three categories: economics, finance and business; engineering; and mathematics, statistics and others. The rate of those who received economics, finance and business education was $76.5 \%$ for Turkish institutional investors, engineering and technical sciences graduates made up $8.1 \%$, and mathematics, statistics, and others made up $15.4 \%$. It should also be noted that some people received education in more than one field.

\subsection{Regression Models and Analysis: Identifying Demographic Factors Associated with Biases}

In this section, the demographic factors that affected the biases that the institutional investor was influenced by in the decisions regarding their individual investments were investigated. With the linear regression analysis "stepwise" method, it was determined which variables most affected the representativeness, conservatism, and overconfidence biases. Regression analyses were performed for the Turkish institutional investors. Survey questions representing the biases were considered as dependent variables. Due to the large number of questions representing the biases in the survey, they were examined one by one, and the survey questions in the Appendix, which were considered to be more meaningful, were included in the regression analysis as the dependent variables.

\subsection{Variables Affecting the Representativeness Bias}

The evaluation of the investors' future predictions regarding security according to past performance is the representativeness bias (Chen et al., 2007). For this reason, it was stipulated that the 38 th question in the survey should pertain to the representativeness bias, and this question was included as a dependent variable in the regression analysis. This question asks the institutional investors whether or not they would invest in previously losing stocks in the future in relation to their individual investments. 
Table 1. Demographic profiles of the respondents.

\begin{tabular}{|c|c|c|}
\hline \multirow[t]{12}{*}{ Current profession } & Commercial bank head office & 39.0 \\
\hline & Bank branch & 14.6 \\
\hline & $\begin{array}{l}\text { Portfolio management } \\
\text { company }\end{array}$ & 1.1 \\
\hline & Investment company & 5.1 \\
\hline & Mutual funds & 0.0 \\
\hline & $\begin{array}{l}\text { Venture capital funds and real } \\
\text { estate investment company }\end{array}$ & 1.4 \\
\hline & Insurance company & 17.1 \\
\hline & Pension funds & 0.8 \\
\hline & Investment bank & 0.0 \\
\hline & Private equity company & 0.0 \\
\hline & Participation bank & 9.6 \\
\hline & Other $^{\mathrm{a}}$ & 11.2 \\
\hline \multirow[t]{3}{*}{ Gender } & Female & 40.3 \\
\hline & Male & 59.7 \\
\hline & Non-binary & 0.0 \\
\hline \multirow[t]{5}{*}{ Age } & $21-30$ & 43.7 \\
\hline & $31-40$ & 38.7 \\
\hline & $41-50$ & 16.0 \\
\hline & $51-60$ & 1.4 \\
\hline & 61 and over & 0.3 \\
\hline \multirow[t]{5}{*}{ Marital status } & Married & 54.6 \\
\hline & Single & 41.7 \\
\hline & Divorced & 3.6 \\
\hline & Separated & 0.0 \\
\hline & Living with partner & 0.0 \\
\hline \multirow[t]{5}{*}{ Children } & No children & 55.2 \\
\hline & 1 Child & 25.4 \\
\hline & 2 Children & 14.4 \\
\hline & 3 Children & 2.0 \\
\hline & More than 3 children & 3.0 \\
\hline \multirow[t]{3}{*}{ Education level } & High school & 2.5 \\
\hline & Some college and bachelor's & 70.9 \\
\hline & Master's and/or Ph.D. & 26.7 \\
\hline \multirow[t]{3}{*}{ Educational profession } & $\begin{array}{l}\text { Economics, finance and } \\
\text { business }\end{array}$ & 76.5 \\
\hline & Engineering & 8.1 \\
\hline & $\begin{array}{l}\text { Mathematics, statistics and } \\
\text { others }^{\text {b }}\end{array}$ & 15.4 \\
\hline \multirow[t]{5}{*}{ Individual experience in the capital markets } & Less than 1 year & 17.0 \\
\hline & $1-2$ Years & 15.6 \\
\hline & $2-3$ Years & 10.9 \\
\hline & $3-4$ Years & 16.1 \\
\hline & 5 Years and longer & 40.3 \\
\hline
\end{tabular}

In the regression analysis for representativeness bias, the $\mathrm{R}^{2}$ value was determined to be $4.6 \%$. According to the $\mathrm{F}$ test result of the model, the p-value was less than 0.05 , and the model was statistically significant. All independent variables were statistically significant in Model 4 since the t-test p-values for the independent variables were less than 0.05 .

The regression equation is as follows:

Representativeness bias $(Q 38)=2.466+0.194 *$ gender $+0.069 *$ experience $-0.040^{*}$ children $/$ not $+0.032^{*}$ education level. 
Table 2. Demographic factors affecting the representativeness bias (Model $4 *$ ).

\begin{tabular}{|c|c|c|c|c|c|c|c|}
\hline \multirow{2}{*}{\multicolumn{2}{|c|}{$\begin{array}{l}\text { Dependent variable: } \\
\text { Question } 38\end{array}$}} & \multirow{3}{*}{$\begin{array}{c}\text { Standardized } \\
\text { coefficients beta }\end{array}$} & \multirow{3}{*}{$\begin{array}{c}\text { Std. } \\
\text { error } \\
\\
0.113 \\
\end{array}$} & \multirow{3}{*}{$\begin{array}{c}\mathbf{t} \\
\\
21.762 \\
\end{array}$} & \multirow{3}{*}{$\begin{array}{c}\mathbf{p} \\
0.000 \\
\end{array}$} & \multicolumn{2}{|c|}{$\begin{array}{c}95.0 \% \\
\text { Confidence } \\
\text { interval for B }\end{array}$} \\
\hline & & & & & & \multirow{2}{*}{$\begin{array}{c}\begin{array}{c}\text { Lower } \\
\text { bound }\end{array} \\
2.244 \\
\end{array}$} & \multirow{2}{*}{$\begin{array}{c}\begin{array}{c}\text { Upper } \\
\text { bound }\end{array} \\
2.688 \\
\end{array}$} \\
\hline $\mathrm{R}^{2}: 4.6 \%$ & Constant & & & & & & \\
\hline & Q5 & -0.040 & 0.012 & -2.411 & 0.016 & -0.052 & -0.005 \\
\hline & $\mathrm{Q}^{7}$ & 0.032 & 0.028 & 2.000 & 0.046 & 0.001 & 0.112 \\
\hline
\end{tabular}

Note: Dependent variable: O38: "If I lost money in some stock(s) in the past, I would never invest in the same stock(s) again in the future".

Independent variables: gender $\left(Q^{2}\right)$, experience $(\mathrm{Q} 10)$, having/not having children $(\mathrm{Q} 5)$, and education level $\left(\mathrm{Q}^{7}\right)$.

* A number of models were tested; other models did not find a high $\mathrm{R}^{2}$ value.

As can be seen from the above regression equation and model in Table 2 , gender (independent variable) was found to be significant in affecting the representativeness bias. Accordingly, among the institutional investors participating in the survey, female institutional investors were more effective than men with the representativeness bias.

Experience is one of the independent variables that was found to be significant in the regression model. The experience of the investor in this case is associated with the long or short period of investment as an individual investor (10th question of the survey).

The institutional investor was envisioned as an experienced investor if they had invested individually in the capital market for a long time. As a result of the analysis, it was understood that institutional investors with one year's experience or less (these are investors who are new to making individual investments and are therefore deemed inexperienced) were more effective than experienced investors in influencing the representativeness bias. In other words, the more time invested (experience), the less the effect on the representativeness bias. It can also be said that investors with less experience are related to the representativeness bias. Baker et al. (2019), on the other hand, determined a direct relationship between experience and the representativeness bias, stating that investors with more experience affect, or are more related to, the representativeness bias. Tekçe, Yılmaz, and Bildik (2016) concluded that experience reduces the representativeness bias.

The variable of children was also one of the independent variables that affected the representativeness bias. It was understood that those who did not have children affected the representativeness bias more. In this case, the fact that those who did not have children were more associated with the representativeness bias, suggesting that more rational investor behavior is displayed after having a child.

Another independent variable that affected the representativeness bias was the education level of the institutional investors. It was concluded that the institutional investors, who were high school graduates, affected the representativeness bias. Institutional investors with a high level of education had less impact on the representativeness bias. In addition to these results, Ateș et al. (2016) also found that a low education level and the representativeness bias were more correlated in their study in Turkey.

To summarize, the representativeness bias in this sample was more affected by female investors who were high school graduates, who did not have children, and who had no experience.

\subsection{Variables Affecting the Conservatism Bias}

Luo (2012) stated that investors with conservative bias move more slowly in changing their mind about an asset when new information about financial assets comes to the market. Barberis, Shleifer, and Vishny (1998) alleged that investors with the conservatism bias think that information on the securities from the market may contain transient elements and therefore it is better to stick with their previous estimates.

In order to determine the factors affecting the conservatism bias in this study, several questions in the survey, which were thought to represent the dependent variable, were tried and many models were created. Consequently, it was determined that the 25 th question in the survey will be the question that best represents conservatism bias and was included as a dependent variable in the regression analysis.

The 25th question asks the institutional investors about a financial asset that they had had a positive experience with in the past, and in the case that future projections and news stories about the financial asset in question were negative, whether or not they would take these negative views into account while making their investment. 
Table 3. Demographic factors affecting the conservatism bias (Model $7 *$ ).

\begin{tabular}{|c|c|c|c|c|c|c|c|}
\hline \multirow{2}{*}{\multicolumn{2}{|c|}{$\begin{array}{l}\text { Dependent variable: } \\
\text { Question } 25\end{array}$}} & \multirow{3}{*}{$\begin{array}{c}\begin{array}{c}\text { Standardized } \\
\text { coefficients } \\
\text { beta }\end{array} \\
2.903\end{array}$} & \multirow{3}{*}{$\begin{array}{c}\text { Std. } \\
\text { error }\end{array}$} & \multirow{3}{*}{$\begin{array}{c}\mathbf{t} \\
21.054\end{array}$} & \multirow{3}{*}{$\begin{array}{c}\mathbf{p} \\
0.000\end{array}$} & \multicolumn{2}{|c|}{$\begin{array}{c}95.0 \% \\
\text { Confidence } \\
\text { interval for B }\end{array}$} \\
\hline & & & & & & \multirow{2}{*}{$\begin{array}{c}\begin{array}{c}\text { Lower } \\
\text { bound }\end{array} \\
2.460 \\
\end{array}$} & \multirow{2}{*}{$\begin{array}{r}\begin{array}{r}\text { Upper } \\
\text { bound }\end{array} \\
2.965\end{array}$} \\
\hline $\mathrm{R}^{2}: 5.8 \%$ & Constant & & & & & & \\
\hline \multirow{6}{*}{$\begin{array}{l}\mathrm{F}: 35.155 \\
\mathrm{p}: 0.0000\end{array}$} & $Q^{7}$ & 0.168 & 0.027 & 10.890 & 0.000 & 0.245 & 0.353 \\
\hline & $Q^{4}$ & -0.191 & 0.040 & -9.586 & 0.000 & -0.460 & -0.303 \\
\hline & Q5 & 0.070 & 0.014 & 3.382 & 0.001 & 0.021 & 0.077 \\
\hline & $\mathrm{Q}^{2}$ & 0.041 & 0.030 & 3.072 & 0.002 & 0.034 & 0.152 \\
\hline & Q10 & 0.048 & 0.015 & 3.289 & 0.001 & 0.020 & 0.081 \\
\hline & Q3 & -0.038 & 0.037 & -2.636 & 0.008 & -0.171 & -0.025 \\
\hline
\end{tabular}

The following regression equation was constructed.

Conservatism Bias $\left(Q^{25}\right)=2.903+0.168 *$ education level $-0.191 *$ marital status $+0.070 *$ having/not children + 0.041 * gender $+0.048 *$ experience $-0.038 *$ age

As can be seen from Table 3, the education level of the institutional investors participating in the survey is one of the variables effective in explaining the conservatism bias. Accordingly, it was determined that the investors who were high school graduates had more influence on the conservatism bias, as per the other biases. Although this is a normal situation for institutional investors, it is assumed that they demonstrate the same rational behavior regarding their individual investments.

Marital status was also one of the variables found to be significant in the regression analysis. The divorced group had a greater influence on the conservatism bias. This effect decreased for single and married people. Barber and Odean (2001) stated that the influence of married couples on the conservatism bias may be due to the influence of married couples on each other. Divorced individuals in this sample were more associated with the conservative bias, perhaps due to decreased responsibilities toward another person, which might have led them to make decisions with biases.

It was observed that those who had one child affected the conservatism bias more than those with more than one child and those without children. Likewise, the effect of those with one child was determined for the overconfidence bias.

It was demonstrated that women were more effective on the conservatism than men. In other words, men's influence on conservative bias was weaker. This situation can be explained by the more conservative behavior of women in their decisions and their late response to market information.

Experience was another variable that influenced the conservatism bias. It was concluded that, especially for institutional investors, those who had individual investments in the securities markets for one year or less affected the conservatism bias more. The greater the experience, the less likely it is to affect the bias. Chen et al. (2007) stated that as investment experience increases, investors will learn to be more rational. Thus, as can be seen from our example, inexperienced people were the ones who affected the bias most. As investors increase their experience, they will move away from the biases and start to display rational investor behavior.

Age was also one of the independent variables that affected the conservatism bias. The age of the participants was divided into two categories for the regression analysis, those who are 40 years old and below and those who are 41 years old and above. Accordingly, it was observed that the institutional investors whose were 41 or older were effective in the conservatism bias.

As a result of the regression analysis, six variables that affect the conservatism bias in the sample were determined. Women who were over 40, inexperienced, high school graduates, divorced, and who have one child had the greatest effect on the conservatism bias. It was found that the effect on the conservative bias decreased as we moved toward those who were experienced, male, had a college or other higher education level, and who have more than one child or no children.

\subsection{Variables Affecting the Overconfidence Bias}

Barber and Odean (2001) showed that the overconfidence bias causes investors to hold underdiversified portfolios. Overconfident investors exaggerate their own judgments, believing that their valuations are stronger and more accurate (Barber \& Odean, 2001) and invest in portfolios that are more risky than rational investors (Barber \& Odean, 2001). De Bondt (1998) also stated that, while institutional investors invest in portfolios that they diversify, individual investors avoid diversifying. Therefore, in the regression analysis for the sample, question 16 was found to be appropriate as the dependent variable and various models were 
created accordingly. The 16th question in the survey asked the respondents whether or not they preferred to create a portfolio in their investments.

As can be seen from Table 4, the variables affecting the overconfidence bias of the institutional investors in the sample as a result of the regression analysis were determined as age, marital status, number of children and education level.

Overconfidence bias $(Q 16)=2.492+0.181^{*}$ education level $+0.157^{*}$ age $-0.174 *$ marital status $+0.108^{*}$ having/not having children

The $\mathrm{R}^{2}$ value of the created model was $7.4 \%$. According to the $\mathrm{F}$ test result of the model, the p-value showed that the model was statistically significant.

Table 4. Demographic factors affecting the overconfidence bias (Model 4*).

\begin{tabular}{|c|c|c|c|c|c|c|c|}
\hline \multirow{2}{*}{\multicolumn{2}{|c|}{$\begin{array}{l}\text { Dependent } \\
\text { variable: Question } \\
16\end{array}$}} & \multirow{3}{*}{$\begin{array}{c}\text { Standardized beta } \\
\text { coefficient } \\
2.492\end{array}$} & \multirow{3}{*}{$\begin{array}{c}\text { Std. error } \\
0.220\end{array}$} & \multirow{3}{*}{$\begin{array}{c}\mathbf{t} \\
11.319\end{array}$} & \multirow{3}{*}{$\begin{array}{c}\mathbf{p} \\
0.000\end{array}$} & \multicolumn{2}{|c|}{$\begin{array}{l}95.0 \% \text { Confidence } \\
\text { interval for B }\end{array}$} \\
\hline & & & & & & \multirow{2}{*}{\begin{tabular}{c|}
$\begin{array}{c}\text { Lower } \\
\text { bound }\end{array}$ \\
2.060 \\
\end{tabular}} & \multirow{2}{*}{$\begin{array}{r}\begin{array}{r}\text { Upper } \\
\text { bound }\end{array} \\
2.924 \\
\end{array}$} \\
\hline \multirow{4}{*}{$\begin{array}{l}\mathrm{R}^{2}: 7.4 \% \\
\mathrm{~F}: 16.598 \\
\mathrm{p}: 0.0000\end{array}$} & Constant & & & & & & \\
\hline & $\mathrm{Q}^{7}$ & 0.181 & 0.065 & 5.694 & 0.000 & 0.244 & 0.500 \\
\hline & $Q^{4}$ & -0.174 & 0.090 & -4.166 & 0.000 & -0.550 & -0.198 \\
\hline & Q5 & 0.134 & 0.034 & 3.154 & 0.002 & 0.041 & 0.175 \\
\hline
\end{tabular}

Note: Dependent variable: Q16: "It is more effective to have a portfolio of financial instruments of the same asset class, e.g., many kinds of stocks or many kinds of bonds". Independent variables: education level $\left(Q^{7}\right)$, age $(\mathrm{Q} 3)$, marital status $(\mathrm{Q} 4)$, having/not having children (Q5)

* A number of models were tested; other models did not find a high $\mathrm{R}^{2}$ value.

One of the variables affecting the overconfidence bias was education level. Accordingly, institutional investors who graduated from high school had an impact on the overconfidence bias. College and university graduates were less influential on the bias than the high school graduates. Master's and other education levels were observed to be the least effective. So, it was generally concluded that those who affected the overconfidence bias were high school graduates rather than university or master's/Ph.D. graduates. Goo et al. (2010) stated that the higher the education level, the higher the investors' self-confidence. In other words, the overconfidence of investors is affected by the level of education graduated, and with this confidence, investors do not follow the information and investment decisions of others (Beatrice et al., 2021).

The independent variable of age was found to be significant in the regression equation. The analysis revealed that the effect of institutional investors aged 40 and under was more effective on the overconfidence bias than those aged 41 and over. In other words, the older the participant, the less they affect the overconfidence bias.

Reaching a similar conclusion, Prims and Moore (2017) also reported that young individuals are affected by overconfidence bias as they are more likely to take risks in their investments.

It was understood that those who had the most effect on the overconfidence bias according to their marital status were divorced. Thus, the influence of divorce was greater than that of married couples or singles. Married couples had the least effect on the overconfidence bias.

In the regression analysis, having/not having children was found to be significant as an independent variable in affecting the overconfidence bias. Those who had one child had more of an effect on the overconfidence bias than the others. Among institutional investors, those who did not have children had the least influence on the overconfidence bias.

Thus, in the sample, the overconfidence bias was affected by the investors who were high school graduates, had one child, were divorced, and were aged 40 or younger.

\section{Results}

Many studies have focused on biases affecting the demographic characteristics of investors (Baker et al., 2019; Barber \& Odean, 2001; Bashir et al., 2013; Beatrice et al., 2021; Bhandari \& Deaves, 2006; Deaves et al., 2009; Dwyer et al., 2002; Goo et al., 2010; Graham et al., 2002; Jianakoplos \& Bernasek, 1998; Lease et al., 1976; Martenson, 2008; Nofsinger et al., 2018; Prims \& Moore, 2017; Prosad et al., 2015; Tekçe et al., 2016). With the regression analysis in this study, the demographic characteristics of the institutional investors, which affected the representativeness, conservatism, and overconfidence biases, were determined. As can be seen from Table 5 below regarding the regression analysis, it was concluded that the biases of the institutional investors were affected by the variables.

To sum up the results regarding the variables that were found to affect the participants' representativeness, conservatism and overconfidence biases, it was observed that the education level variable, especially high school graduates, affected all three biases that were examined in this study. In other words, among the investors, those with low levels of education interacted more with the aforementioned biases in their decisions regarding their individual investments. According to this result, one may state that an 
institutional investor who is expected to have a specialized or college/university would have a more limited interaction with biases in comparison to investors who are high school graduates by not deviating from their identity as a rational investor, even in their individual investments. This implies that institutional investors continue to make rational decisions, even in their individual investments. On the other hand, Mishra and Metilda (2015) found that overconfidence levels increased in direct proportion to education. Nevertheless, Baker et al. (2019) reported that individuals with a high level of education (e.g., university, college, master's, doctorate) were less influenced by representativeness bias.

Table 5. Summary of regression analysis.

\begin{tabular}{l|l|l}
\hline Biases & $\begin{array}{l}\text { Independent variables affecting } \\
\text { biases according to the } \\
\text { regression analysis }\end{array}$ & $\begin{array}{l}\text { Subgroups of the independent } \\
\text { variables affecting the biases in } \\
\text { the regression analysis }\end{array}$ \\
\hline Representativeness & Experience & -1 Year or less \\
bias & Gender & - Female \\
& Education level & - High school \\
& Having/not having children & - No children. \\
\hline Conservatism bias & Age & -41 and over \\
& Education level & - High school \\
& Marital status & - Divorced \\
& Having/not having children & -1 Child \\
& Gender & - female \\
& Experience & -1 Year or less \\
\hline Overconfidence bias & Having/not having children & -1 Child \\
& Age & -40 and under \\
& Marital status & - Divorced \\
& Education level & - High school \\
\hline
\end{tabular}

Furthermore, it was seen in this study that the variable for having/not having a child was associated with all three biases. Nonetheless, while the institutional investors who had one child affected conservatism and overconfidence biases, those who did not have any children affected representativeness bias. Hence, it may be concluded that as institutional investors who have multiple children have increased levels of responsibility, they display rational investor behaviors by not interacting with biases not only in investments directly associated with their profession but also in their individual investments.

Mishra and Metilda (2015) determined gender to be a variable associated with biases. In this study, it was also discovered that gender was an influential variable on both representativeness and conservatism biases, especially among female investors. Although several studies have determined a relationship between the female gender and overconfidence bias, in this study, no such link was identified. Studies by Baker et al. (2019) and many other researchers (Barber \& Odean, 2001; Bhandari \& Deaves, 2006; Kumar \& Goyal, 2016; Lin, 2011) have demonstrated that men have an increased tendency toward overconfidence bias. By reporting on the variables of experience and gender together, Baker et al. (2019) revealed that men who have experience in terms of investment are more overconfident. When the variables of experience and gender were analyzed together in this study, as opposed to the findings of Baker et al. (2019), it was revealed that inexperienced and female investors were influenced more by representativeness and conservatism biases.

The 10th question in the survey was about the investment experience of the institutional investor regarding their individual investments, where experience was defined based on the number of years of investment in capital markets. It was discerned that representativeness and conservatism biases were influenced more by the investors who had very little experience/inexperienced. Similarly, Baker et al. (2019) identified a relationship between being young or inexperienced and representativeness bias. Prosad et al. (2015) stated that people with little investment experience, who acted in accordance with the representativeness bias, rely on the knowledge and advice of external sources rather than their own knowledge. Deaves et al. (2009) determined that investors who gain experience over time will reduce their transaction volumes and will not be affected by behavioral biases in investment decisions and will exhibit rational investor behavior.

In addition to the variable of gender, Mishra and Metilda (2015) determined that experience and the education level of investors were also related to biases. Gervais and Odean (2001) argued that experienced investors will affect overconfidence, to at least a certain extent.

In this study, it was observed that both conservatism and overconfidence bias were affected by the divorced institutional investors. Considering that couples influence each other in their investment decisions, and their likelihood to be affected by overconfidence bias would diminish (Barber \& Odean, 2001), with the inference that divorced institutional investors make decisions alone in their individual investments and act independently, it may be stated that they would interact with biases, and their divorced status would influence their status of having biases. 
Finally, regarding the age variable, it was seen that being an institutional investor at the age of 40 or younger affected overconfidence bias in individual investments, whereas being over the age of 40 affected conservatism bias. The finding that the conservatism bias was influenced by the participants over the age of 40 suggests that this age group is more conservative regarding past information. Tekçe et al. (2016) found that Turkish investors are affected by the representativeness bias as their age increases. Baker et al. (2019) similarly reported that age, occupation, and investment experience were demographic factors associated with biases among individual investors.

\section{References}

Asad, H., Khan, A., \& Faiz, R. (2018). Behavioral biases across the stock market investors: evidence from Pakistan. Pakistan Economic and Social Review, 56(1), 185-209.

Ateş, S., Coşkun, A., Şahin, M. A., \& Demircan, M. L. (2016). Impact of financial literacy on the behavioral biases of individual stock investors: evidence from Borsa Istanbul. Business \& Economics Research Journal, 7(3), 1-19. https://doi.org/10.20409/berj.2016321805

Baker, H. K., Kumar, S., Goyal, N., \& Gaur, V. (2019). How financial literacy and demographic variables relate to behavioral biases. Managerial Finance, 45(1), 124-146. https://doi.org/10.1 108/mf-01-2018-0003

Barber, B. M., \& Odean, T. (2001). Boys will be boys: Gender, overconfidence, and common stock investment. The Quarterly Journal of Economics, $116(1), 261-292$.

Barberis, N., Shleifer, A., \& Vishny, R. (1998). A model of investor sentiment. Journal of Financial Economics, 49(3), 307343.

Bashir, T., Azam, N., Butt, A. A., Javed, A., \& Tanvir, A. (2013). Are behavioral biases influenced by demographic characteristics \& personality traits? Evidence from Pakistan. European Scientific Journal, 9(29), 1857 - 1881.

Beatrice, V., Murhadi, W. R., \& Herlambang, A. (2021). The effect of demographic factors on behavioral biases. Journal of Business Strategy, 25(1), 17-29. https://doi.org/10.20885/jsb.vol25.iss1.art2

Bhandari, G., \& Deaves, R. (2006). The demographics of overconfidence. The Journal of Behavioral Finance, 7(1), 5-11.

Chen, G., Kim, K. A., Nofsinger, J. R., \& Rui, O. M. (2007). Trading performance, disposition effect, overconfidence, representativeness bias, and experience of emerging market investors. Journal of Behavioral Decision Making, $20(4), 425-451$.

Daniel, K., Hirshleifer, D., \& Subrahmanyam, A. (2005). Investor psychology and security market under-and overreaction. The Journal of Finance, 53(6), 1839-1885.

De Bondt, W. F. (1998). A portrait of the individual investor. European Economic Revierw, 42(3-5), 831-844. https://doi.org/10.1016/s0014-2921(98)00009-9

Deaves, R., Lüders, E., \& Luo, G. Y. (2009). An experimental test of the impact of overconfidence and gender on trading activity. Review of Finance, 13(3), 555-575. https://doi.org/10.1093/rof/rfno23

Dreman, D. N., \& Berry, M. A. (1995). Overreaction, underreaction, and the low-P/E effect. Financial Analysts Journal, 51(4), 21-30. https://doi.org/10.2469/faj.v51.n4.1917

Dwyer, P. D., Gilkeson, J. H., \& List, J. A. (2002). Gender differences in revealed risk taking: Evidence from mutual fund investors. Economics Letters, 76(2), 151-158. https://doi.org/10.1016/s0165-1765(02)00045-9

Gervais, S., \& Odean, T. (2001). Learning to be overconfident. The Review of Financial Studies, 14(1), 1-27.

Goo, Y.-J., Chen, D.-H., Chang, S.-H. S., \& Yeh, C.-F. (2010). A study of the disposition effect for individual investors in the Taiwan stock market. Emerging Markets Finance and Trade, 46(1), 108-1 19. https://doi.org/10.2753/ree1540$496 \times 460110$

Graham, J. F., Stendardi, E. J., Myers, J. K., \& Graham, M. J. (2002). Gender differences in investment strategies: An information processing perspective. International Journal of Bank Marketing, 20(1), 17-26.

Ji, L. J., Zhang, Z., \& Guo, T. (2008). To buy or to sell: Cultural differences in stock market decisions based on price trends. Journal of Behavioral Decision Making, 21(4), 399-413. https://doi.org/10.1002/bdm.595

Jianakoplos, N. A., \& Bernasek, A. (1998). Are women more risk averse? Economic Inquiry, 36(4), 620-630. https://doi.org/10.1111/j.1465-7295.1998.tb01740.x

Kumar, S., \& Goyal, N. (2016). Evidence on rationality and behavioural biases in investment decision making. Qualitative Research in Financial Markets, 8(4), 270-287. https://doi.org/10.1108/qrfm-05-2016-0016

Lascu, D. N., Babb, H. W., \& Phillips, R. W. (1997). Gender and investment: The influence of gender on investment preferences and practices. Managerial Finance, 23(10), 69-83. https://doi.org/10.1108/eb0 18652

Lease, R. C., Lewellen, W. G., \& Schlarbaum, G. G. (1976). Market segmentation: Evidence on the individual investor. Financial Analysts Journal, 32(5), 53-60. https://doi.org/10.2469/faj.v32.n5.53

Lin, H.-W. (2011). Elucidating the influence of demographics and psychological traits on investment biases. International Journal of Economics and Management Engineering, 5(5), 424-429.

Luo, G. Y. (2012). The psychological explanation of asset price overreaction and underreaction to new information: Representativeness heuristic and conservatism bias. Journal of Accounting and Finance, 12(2), 38-50.

Martenson, R. (2008). Are men better investors than women? Gender differences in mutual fund and pension investments. Journal of Financial Services Marketing, 13(1), 72-81. https://doi.org/10.1057/fsm.2008.7

Menkhoff, L., Schmeling, M., \& Schmidt, U. (2013). Overconfidence, experience, and professionalism: An experimental study. Journal of Economic Behavior \& Organization, 86, 92-101. https://doi.org/10.1016/j.jebo.2012.12.022

Mishra, K., \& Metilda, M. J. (2015). A study on the impact of investment experience, gender, and level of education on overconfidence and self-attribution bias. IIMB Management Review, 27(4), 228-239. https://doi.org/10.1016/j.iimb.2015.10.004

Nikiforow, M. (2009). Does training on behavioral finance influence fund managers' perception and behavior? Leibniz Universität, Working Paper. No. 419. 
Nofsinger, J. R., Patterson, F. M., \& Shank, C. A. (2018). Decision-making, financial risk aversion, and behavioral biases: The role of testosterone and stress. Economics \& Human Biology, 29(4), 1-16. https://doi.org/10.1016/j.ehb.2018.01.003

Prims, J. P., \& Moore, D. A. (2017). Overconfidence over the lifespan. Judgment and Decision Making, 12(1), $29-41$.

Pronin, E., Lin, D. Y., \& Ross, L. (2015). The bias blind spot: perceptions of bias in self versus others. Personality and Social Psychology Bulletin, 28(3), 369-381. https://doi.org/10.1177/0146167202286008

Prosad, J. M., Kapoor, S., \& Sengupta, J. (2015). Behavioral biases of Indian investors: A survey of Delhi-NCR region. Qualitative Research in Financial Markets, 7(3), 230-263.

Tekçe, B., Yılmaz, N., \& Bildik, R. (2016). What factors affect behavioral biases? Evidence from Turkish individual stock investors. Research in International Business and Finance, 37, 515-526. https://doi.org/10.1016/j.ribaf.2015.1 1.017

Appendix

Survey questions.

10. How long have you been investing for?

$\square$ 1. Less than 1 year

$\square$ 2. 1-2 years

$\square$ 3. 2-3 years

4. 3-4 years

$\square$ 5. 5 years and longer

16. It is more effective to have a portfolio of financial instruments of the same asset class (e.g., many kinds of stocks or many kinds of bonds)

$\square$ 1. Strongly agree

2. Agree

3. Neither agree nor disagree

4. Disagree

5. Strongly disagree

25. If I had a positive experience investing in a stock, I don't take into account any negative developments or news about this stock in future.

1. Strongly agree

2. Agree

3. Neither agree nor disagree

4. Disagree

5. Strongly disagree

38. If I lost money in some $\operatorname{stock}(s)$ in the past, I would never invest in the same stock(s) again in the future.

$\square$ 1. Strongly agree

$\square$ 2. Agree

$\square$ 3. Neither agree nor disagree

$\square$ 4. Disagree

5. Strongly disagree 